\title{
Screening of Potential Biosurfactant Producing Bacteria from Tanjung Perak Port, Surabaya
}

\author{
Marlinda Elvina Susanti ${ }^{1 *}$, Maftuch², Asep Awaludin Prihanto ${ }^{2}$ \\ ${ }^{1}$ Master Program of Aquaculture, Faculty of Fisheries and Marine Sciences, University of Brawijaya, Malang, Indonesia \\ ${ }^{2}$ Faculty of Fisheries and Marine Sciences, University of Brawijaya, Malang, Indonesia
}

Abstract

Bacteria are bioremediation agents that are advised to overcome water pollution. This study aims to isolate biosurfactant-producing bacteria for bioremediation from Tanjung Perak Port, Surabaya. The isolates grown in specific media were tested for drop collapse, oil spreading test, and emulsification index. A total of 12 bacterial isolates were isolated from Tanjung Perak seawater contaminated with diesel oil. In the drop collapse test, four isolates had the highest positive score from this test, isolate LU-5, LU-7, LU-9, and LU-11. While in the second test, the oil spreading test, the highest positive score results were obtained in three isolates, isolates LU-2, LU-7, and LU-11. The emulsification index (E24) value showed that isolates LU-7, LU-9, and LU-11 were significantly higher than the others, which was above 10\%. This study concludes that in Tanjung Perak, seawater-contaminated oil isolated several bacteria that produce biosurfactants, which have the potential to be developed as bioremediation agents.

Keywords: bacteria, bioremediation, biosurfactant, diesel oil

\section{INTRODUCTION}

Water pollution is a crucial environmental issue that continues to occur, especially in marine waters. The primary source of marine contamination is derived from oil spills both from offshore drilling processes and from activities by ships that cross the ocean [1]. A site that gets an opportunity of an oil spill is the port. Tanjung Perak is the second most significant and active port in Indonesia after Tanjung Priok. To this day, Tanjung Perak is a port used as a trading center in eastern Indonesia. Bunkering activities in the port area or refueling diesel oil when ships are more frequently contributing waste oil spills. This activity can harm life resources, disrupt marine activities, including fishing, marine culture, and decrease seawater quality, up to human health problems [2].

There are different approaches to reduce the impact of oil contamination physically, chemically, and biologically. Biological treatment of oil spills in bioremediation techniques is the most effective and economical way. As well as having a small environmental effect, this method can significantly reduce the oil spills impacts [3]. Bioremediation works by decomposing or reducing toxic organic and inorganic waste in the environment into other harmless compounds. A SWOT analysis for bioremediation technologies

\footnotetext{
*Correspondence address:

Marlinda Elvina Susanti

Email : marlindaelvina@gmail.com

Address : Faculty of Fisheries and Marine Sciences, University of Brawijaya, Veteran Malang, 65145
}

showed that the bioremediation agents are predominantly bacteria (57\%), enzymes (19\%), fungi $(13 \%)$, algae $(6 \%)$, plants $(4 \%)$, and protozoa [4]. Indigenous bacteria as a bioremediation agent are advised. Bacteria are one type of microorganism with a very high abundance in nature, both in terms of number and type. Bacteria that can degrade compounds contained in petroleum hydrocarbons are called hydrocarbonoclastic bacteria.

Biosurfactants are surfactants produced by microorganisms, especially bacteria. Currently, this active compound has gained significant attention as an emulsifier and oil recovery agent. It is because biosurfactants have high efficiency and selectivity. Biosurfactants can work in extreme conditions (salinity, $\mathrm{pH}$, and temperature) with high biodegradability and low toxicity [5]. Several types of bacteria can produce surfactants that allow them to degrade or alter insoluble organic compounds, one of which is diesel oil. In addition, biosurfactants can increase surface area and oil solubility. Therefore, this study will discuss the potential of bacteria indigenous from the Tanjung Perak Port in producing biosurfactants by several screening methods.

\section{MATERIAL AND METHOD Samples Collection}

Water samples were collected from the port of Tanjung Perak Surabaya, $7^{\circ} 19^{\prime} 97,60^{\prime}$ south latitude and $112^{\circ} 73^{\prime} 18,42^{\prime}$ east longitude (Fig. 1). The sampling method in this study used the purposive sampling method. A sample of 1000 $\mathrm{mL}$ of seawater was taken from the port of 
Tanjung Perak, Surabaya. The sampling site was in an area that had experienced an oil spill. Insite water quality measurements are carried out directly at the location. Water temperature and $\mathrm{pH}$ were measured by a $\mathrm{pH}$ meter (Lutron $\mathrm{PH}$ 220). Other water quality parameters measured in the laboratory include salinity with a salinometer and oil content (APHA.5220 B-2017). The water sample was then placed in sterilized bottles and stored in an icebox at $4^{\circ} \mathrm{C}$. It was stored for around 2 hours until arriving at the laboratory for further analysis.

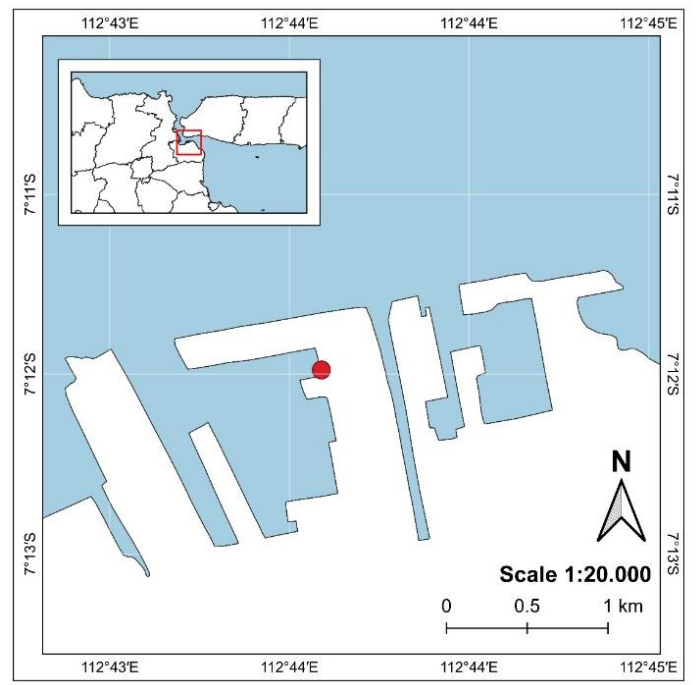

Figure 1. Sampling Location at Tanjung Perak Port

\section{Isolation of Bacteria}

The pure water samples were homogenized using a water bath incubator shaker (Memmert wnb 22, Germany) at $30^{\circ} \mathrm{C}$ for 1 hour, $170 \mathrm{rpm}$ speed shaker. Then, one $\mathrm{ml}$ of the sample was transferred to a tube containing $9 \mathrm{ml}$ of $0.85 \%$ $\mathrm{NaCl}$, followed by serial dilutions up to $10^{-5}$. Next, the isolation was carried out using the spread plate method, and $0.1 \mathrm{~mL}$ of water sample from $10^{-5}$ dilutions were cultured in Nutrient Agar (NA) medium $+1 \%$ diesel oil (as an additional carbon source) and incubated for $24-48$ hours at $30^{\circ} \mathrm{C}$ [6].

\section{Morphological Characterization of Bacteria Colony}

After incubation, different bacterial colonies that appeared on the agar surface were taken and transferred for characterization. The morphological characterization of bacterial colonies was carried out macroscopically and microscopically. Macroscopic observations mark the shape, color (pigmentation), elevation, and margins in this study. While the microscopic characterization was carried out by Gram staining using a microscope with a magnification of 400x. This physical characterization was determined based on Harley-Prescott [7]. The selected colonies were purified into NA medium using the streak plate method. The pure isolates were stored in slanted agar and Nutrient Broth (NB) medium with glycerol, then stored in a refrigerator at $4^{\circ} \mathrm{C}$ for further analysis.

\section{Screening of Biosurfactant-Producing Isolates Drop collapse test}

All of the screening tests in this study used Nutrient Broth as a medium. The drop collapse test was performed by dripping two microliters of diesel oil onto a parafilm surface followed by five microliters drops of $24 \mathrm{~h}$ culture supernatants of each isolate. After 1 minute of observation, the supernatant made the oil drop collapse and will be flat if it contains biosurfactants [8]. It scored as positive results. On the other hand, if the droplets remain spherical, the isolate was scored as negative results. These results can be compared with distilled water as a control.

\section{Oil spreading assay}

The oil spreading test was performed by pouring $50 \mathrm{ml}$ of distilled water into a petri dish (9 $\mathrm{cm}$ diameter). Later, $50 \mu \mathrm{L}$ of diesel oil was dropped onto the surface of the water. The $24 \mathrm{~h}$ culture supernatant $(10 \mu \mathrm{L})$ of each isolate was then added to the diesel oil surface. The clear zone was observed if the biosurfactant was present, and, subsequently, the diameter of the clear area was measured after $30 \mathrm{~s}$ [8].

\section{Emulsification index $\left(E_{24}\right)$}

The emulsification test is used to determine the ability of biosurfactants to emulsify liquids of different polarities. The $24 \mathrm{~h}$ culture supernatant incubated at $30^{\circ} \mathrm{C}$ of each isolate was mixed with diesel oil. The test was used a test tube $(16 \mathrm{~mm}$ diameter, $100 \mathrm{~mm}$ high) in a $1: 1$ ratio $(1.5 \mathrm{~mL}$ supernatant mixed with $1.5 \mathrm{~mL}$ diesel oil). The mixture was vortexed at high speed for 2 minutes and then left for 24 hours to form a stable emulsion. Emulsification test results are expressed as the emulsification index [9]. The percentage of emulsification index was calculated following the formula.

Description:

$$
E_{24}(\%)=\frac{H E}{H T} \times 100
$$

$\mathrm{HE}$ : the height of emulsion layer $(\mathrm{cm})$ $\mathrm{HT}$ : total height of liquid column $(\mathrm{cm})$ 


\section{Statistical Analysis}

All emulsification indexes were performed in duplicate. Ms. Excel version 2008 was used for statistical analysis. Data presented are mean value \pm standard deviation.

\section{RESULT AND DISCUSSION}

\section{Physiochemical Properties of Water Sample}

Water samples were collected from the Tanjung Perak port area that contaminated diesel oil. In addition to seawater sampling, physical and chemical parameters were measured. The physicochemical properties of the water analyzed from the sample will affect the results of the isolated microorganisms. The results of the analysis are shown in Table 1.

Table 1. Water Quality Analysis

\begin{tabular}{clcc}
\hline No. & Parameter & Result & Unit \\
\hline 1 & Temperature & 31.4 & ${ }^{\circ} \mathrm{C}$ \\
2 & $\mathrm{pH}$ & 6.58 & - \\
3 & Salinity & 26.2 & $\mathrm{ppt}$ \\
4 & Oil Content & 2.0 & $\mathrm{mg} \cdot \mathrm{L}^{-1}$ \\
\hline
\end{tabular}

Temperature can affect the rate of biochemical reactions. The reaction rate will double for every $10^{\circ} \mathrm{C}$ increase in temperature. At a temperature of $31.4^{\circ} \mathrm{C}$, the bacteria that grow well are mesophilic. The results of the salinity measurement of $26.2 \mathrm{ppt}$ indicate that the location is brackish waters. With this salinity, bacteria that can live are a group of halophilic bacteria [10].

According to the Government Regulation (PP) Number 22, in the year 2021, the detected oil concentration still fulfills the standard of port water quality. However, these are not suitable for marine biota that lives in this area [11]. The concentration of oil that pollutes the waters will also affect the number of isolates found. Hydrocarbonoclastic bacteria in their life activities require carbon molecules as a source of nutrition and energy to metabolize and reproduce [12]. These bacteria can degrade oil waste by using existing carbon as a source of energy and nutrients for growth.

\section{Isolation and Morphology Characterization of Bacteria}

Twelve pure isolates were obtained from the isolation process. The results of the morphological characterization are visualized in Table 2. Based on the morphological characteristics process, from the 12 isolates, the average colony was irregular. Several isolates were circular in shape, and one isolate was punctiform. Most of the colors of the colonies were cream, while only three colonies were white. The elevation of the 12 isolates was dominated by prominent convex colonies. Only some colonies had raised elevations. Characteristics based on margin indicate entire and undulate. Meanwhile, the Gram staining results showed that $66.7 \%$ of the isolates were gram-negative bacteria, and $83.3 \%$ were rods. Similar to another study reported that gramnegative bacteria isolated from water contaminated with diesel oil is more than the gram-positive bacteria [6].

Several studies report the results of bacteria that have been isolated from waters affected by oil spills, and there are Vibrio alginolyticus [13], Bacillus cereus [14], Alcanivorax nanhaiticus and Halomonas meridiana [15], Aeromonas hydrophila, Enterobacter agglomerans, Shewanella putrefaciens, and Acinetobacter haemolyticus [3]. In addition, biosurfactants are secondary metabolite products from bacteria that can increase hydrocarbons emulsification and help facilitate the degradation process. In this study, all identified isolates were evaluated for their ability to produce biosurfactants.

Table 2 . Morphology of Colony Characterization

\begin{tabular}{|c|c|c|c|c|c|c|}
\hline \multirow{2}{*}{ Isolates Code } & \multicolumn{4}{|c|}{ Macroscopic } & \multicolumn{2}{|c|}{ Microscopic } \\
\hline & Form & Colour & Elevation & Margin & Gram & Shape \\
\hline LU-1 & Punctiform & Cream & Raised & Undulate & Positive & Cocci \\
\hline LU-2 & Irregular & Cream & Convex & Undulate & Positive & Rods \\
\hline LU-3 & Circular & Cream & Convex & Entire & Positive & Rods \\
\hline LU-4 & Circular & Cream & Raised & Entire & Negative & Rods \\
\hline LU-5 & Circular & White & Convex & Entire & Negative & Rods \\
\hline LU-8 & Irregular & White & Raised & Undulate & Negative & Rods \\
\hline LU-9 & Circular & Cream & Convex & Entire & Negative & Rods \\
\hline LU-10 & Irregular & White & Raised & Undulate & Negative & Cocci \\
\hline LU-11 & Irregular & White & Convex & Undulate & Negative & Rods \\
\hline LU-12 & Irregular & White & Convex & Undulate & Positive & Rods \\
\hline
\end{tabular}




\section{Biosurfactant-Producing Bacteria Screening}

The results of this study confirm that the oilcontaminated area is a potential place to obtain biosurfactant-producing microorganisms. Twelve isolates with different morphologies are able to produce biosurfactants with varying ability levels (Table 3).

Table 3. Screening of Biosurfactant Producing Bacteria

\begin{tabular}{lcc}
\hline \multirow{2}{*}{ Isolate Code } & \multicolumn{2}{c}{ Screening Biosurfactant } \\
\cline { 2 - 3 } & $\begin{array}{c}\text { Drop Collapse } \\
\text { Test }\end{array}$ & $\begin{array}{c}\text { Oil Spreading } \\
\text { Test (mm) }\end{array}$ \\
\hline Control & - & - \\
LU-1 & + & ++ \\
LU-2 & + & +++ \\
LU-3 & + & +++ \\
LU-4 & + & +++ \\
LU-5 & ++ & +++ \\
LU-6 & + & +++ \\
LU-7 & ++ & ++++ \\
LU-8 & + & ++ \\
LU-9 & ++ & +++ \\
LU-10 & + & +++ \\
LU-11 & ++ & ++++ \\
LU-12 & + & + \\
\hline
\end{tabular}

*Drop collapse test (DCT) [24] :

(-) completely spherical, (+) slightly flat, and (++) flat. **Oil spreading test (OST) based on the diameter of the clear zone : (-) no diameter, (+) diameter $\leq 10 \mathrm{~mm},(++)$ diameter 10-30 mm, (+++) diameter $30-50 \mathrm{~mm}$ and (++++) diameter $\geq 50 \mathrm{~mm}$.

\section{Drop collapse test}

The biosurfactant test using the drop collapse method is based on the destabilization of the bacterial supernatant droplets containing the biosurfactant [16]. If the droplets are round and stable, the polar water molecules will attract the water surface of the hydrophobic surface of the oil [17]. The results of the drop collapse test in this study showed that none of the isolates produced round and stable droplets as in the control. So, it was revealed that the 12 isolates were able to produce biosurfactants. Of all isolates producing biosurfactants, LU-5, LU-7, LU9, and LU-11 showed the highest positive score with flat drops. The droplet is flat because the interfacial tension between the sample and the oil decreases.

\section{Oil spreading test}

The oil spreading test is a fast, easy and sensitive method used to detect biosurfactant activity. The results of oil spreading showed that the 12 bacterial isolates dripped onto a layer of oil and water could form a clear zone. The diameter of the clear zone indicates the activity of surfactants, which is also known as oil displacement [18]. In contrast to the control, which did not form a clear area. It was due to the absence of the addition of bacterial isolates to the test medium so that there was no bacterial activity to utilize carbon sources in producing biosurfactants [19].

The diameter of the clear zone diameter formed in isolates LU-2, LU-7, and LU-11 was greater than $50 \mathrm{~mm}$. The diameter of the clear zone of the three isolates was more significant than that of the other isolates. Thus, this indicates the presence of a higher concentration of biosurfactant. Oil spreading test results were in corroboration with drop collapse test results. Strains found with positive drop collapse results were positive for the oil spreading test also. These two methods are recommended for testing biosurfactant production [20].

\section{Emulsification index (E24)}

The emulsification assay technique as the quantitative method can be used for screening of the biosurfactant producers. This method is the most promising one because they are more reliable and accurate to confirm the presence of biosurfactant [21]. The emulsification ability of the biosurfactants produced by the 12 bacterial isolates was determined based on the measurement of the emulsification index $\left(E_{24}\right)$. The results showed that all isolates had different emulsification index values (Fig 2).

The highest $E_{24}$ value was produced by isolating LU-7 and LU-11 with the same percentage of $14.81 \%$. The LU-9 isolate also had a relatively high $E_{24}$ value of $12.96 \%$. Based on the characteristic isolates LU-7, LU-9, and LU-11 were gram-negative bacteria. Similar to another study, the gram-negative bacteria have a high emulsification capacity. Gram-negative bacterium $\mathrm{O} 15$ isolated from seawater produced $65 \%$ of the highest emulsification and demonstrated biosurfactant production in the other biosurfactant screening method [22].

Thus, from this test, three isolates were obtained, which could be considered potential biosurfactant producers. Isolates with better emulsification value show the ability to utilize oil more effectively. It is related to the mechanism of biosurfactants in increasing oil degradation. It increases the bioavailability of the substrate through emulsification [23]. 


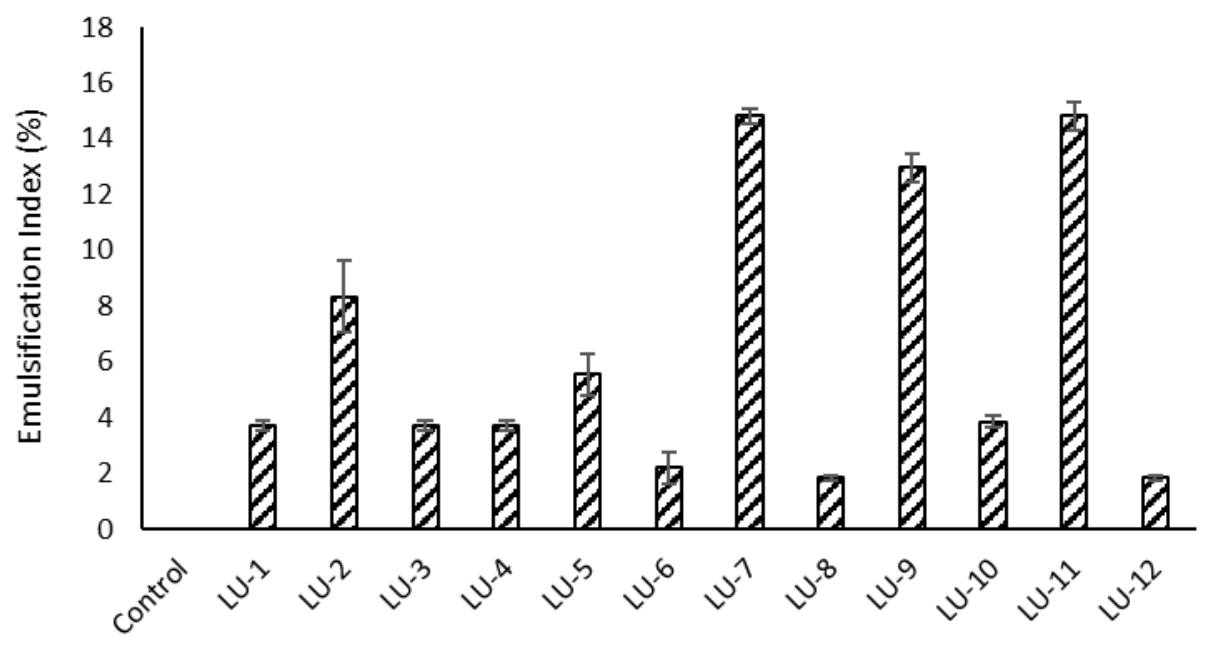

Isolate Code

Fig 2. Emulsification Index $\left(E_{24}\right)$. Error bars indicate standard deviation

\section{CONCLUSION}

Indigenous bacteria that produce biosurfactants are found quite a lot in the waters of the Tanjung Perak Port. A total of 12 isolates were found, and all of them can produce biosurfactants with different abilities. The screening results found that the three best isolates were LU-7, LU-9, and LU-11 isolates. The discovery of biosurfactant-producing bacteria indicates that in this area can be found biosurfactant-producing bacteria that have the potential as bioremediator. However, further research is needed to identify these potential bacteria and determine their ability to degrade the oil.

\section{REFERENCES}

[1] Sulistyono. 2013. Dampak tumpahan minyak (oil spill) di perairan laut pada kegiatan industri migas dan metode penanggulangannya. Forum Teknologi. 3(1). 49-57.

[2] Beiras, R. 2018. Basic concepts: Sources, fate and effects of pollutants in coastal ecosystems. Mar. Pollut. 147. 1-11.

[3] Yeti, D., N.F. Afianti. 2017. Penerapan dan tingkat efektivitas teknik bioremediasi untuk perairan pantai tercemar minyak. OSEANA. XLII. 55-69.

[4] Quintella, C. M., A.M.T. Mata, L.C.P. Lima. 2019. Overview of bioremediation with technology assessment and emphasis on fungal bioremediation of oil contaminated soils. J. Environ. Manage. 241. 156-166.

[5] Ismail, A. S., H.S. El-Sheshtawy, N.M. Khalil, 2019. Bioremediation process of oil spill using fatty-lignocellulose sawdust and its enhancement effect. Egypt. J. Pet. 28(2). 205-211.

[6] Pranowo, P.P., H.S. Titah. 2016. Isolation and screening of diesel-degrading bacteria from the diesel contaminated seawater at Kenjeran Beach, Surabaya. EnvironmentAsia. 9(2). 165-169.

[7] Harley, J.P., L.M. Prescott. 2002. Laboratory Exercise in Microbiology 5th edition. McGraw-Hill. New York.

[8] Almansoory, A. F., M. Idris, S. Abdullah, N. Anuar. 2014. Screening for potential biosurfactant producing bacteria from hydrocarbon-degrading isolates. $A d v$. Environ. Biol. 8(3). 639-647.

[9] Mouafo, T.H., A. Mbawala, R. Ndjouenkeu. 2018. Effect of different carbon sources on biosurfactants' production by three strains of Lactobacillus spp. BioMed Research International. 2018(1). 1-15.

[10] Lubis, S.S. 2015. Penapisan bakteri laut penghasil antimikroba dari Pesisir Serdang Bedagai Sumatera Utara. J. Islam. Sci. Technol. 1(1). 87-96.

[11] Republic of Indonesia. 2021. Goverment Regulation No. 22 about Implementation of Environmental Protection and Management: Seawater Quality Standards. Republic of Indonesia. Jakarta.

[12] Rahayu, Y.S., Yuliani, G. Trimulyono. 2019. Isolation and identification of hydrocarbon degradation bacteria and phosphate solubilizing bacteria in oil contaminated soil 
in Bojonegoro, East Java, Indonesia. Indonesian J. Sci. Technol. 4(1). 134-147.

[13] Imron, M.F., S.B. Kurniawan, H.S. Titah. 2019. Environmental technology and innovation potential of bacteria isolated from diesel-contaminated seawater in diesel biodegradation. Environ. Technol. Innov. 14. 2-10.

[14] Ramadhani, A., T. Wahyuni, E.Y. Herawati, A. Kurniawan, A.A. Amin. 2019. Isolation, and identification of diesel oil degrading bacteria in water contamination site and preliminary analysis with potential bacterial Gordonia terrae. Res. J. Life Sci. 6(2). 141149.

[15] Puspitasari, I., A. Trianto, J. Suprijanto. 2020. Eksplorasi bakteri pendegradasi minyak dari perairan Pelabuhan Tanjung Mas, Semarang. J. Mar. Res. 9(3). 281-288.

[16] Ewida, A.Y.I., W.S. El-din Mohamed. 2019. Isolation and characterization of biosurfactant producing bacteria from oilcontaminated water. Biosci. Biotechnol. Res. Asia. 16(4). 833-841.

[17] Wibisana, A. 2018. Isolasi dan skrining mikroba penghasil biosurfaktan dari air laut yang tercemar minyak. Jurnal IImiah Teknik Kimia. 2(2). 55.

[18] Syakti, A.D., P. Lestari, S. Simanora, L.K. Sari, F. Lestari, F. Idris, T. Agustiadi, S. Akhlus, N.V. Hidayati, Riyanti. 2019. Culturable hydrocarbonoclastic marine bacterial isolates from Indonesian seawater in the Lombok Strait and Indian Ocean. Heliyon. 5(5). e01594.

[19] Najiyah, D., N. Vita, C. Nanda. 2013. Manfaat surfaktan dari bakteri laut hidrokarbonoklastik untuk akselerator proses hidrokarbon minyak bumi. Lembaran Publikasi Minyak dan Gas Bumi. 47(2). 97-104.

[20] Thavasi, R., S. Sharma, S. Jayalakshmi. 2013. Evaluation of screening methods for the isolation of biosurfactant producing marine bacteria. J. Pet. Environ. Biotechnol. 4(2). DOI: 10.4172/2157-7463.S1-001.

[21] Sidkey, N., H. Mohamed, H. Elkhouly. 2016. Evaluation of different screening methods for biosurfactant producers isolated from contaminated Egyptian samples grown on industrial olive oil processing waste. $\mathrm{Br}$. Microbiol. Res. J. 17(4). 1-19.

[22] Hassanshahian, M. 2014. Isolation and characterization of biosurfactant producing bacteria from Persian Gulf (Bushehr provenance). Mar. Pollut. Bul. 86(1-2). 361-366.

[23] Patowary, K., R. Patowary, M.C. Kalita, S. Deka. 2017. Characterization of biosurfactant produced during degradation of hydrocarbons using crude oil as sole source of carbon. Front.Microbiol. 8(2). 114.

[24] Wu, Y., M. Xu, J. Xue, K. Shi, M. Gu. 2019. Characterization and enhanced degradation potentials of biosurfactant-producing bacteria isolated from a marine environment. ACS Omega. 4(1). 1645-1651. 